\title{
Nutrient, pH, Alkalinity, and Ionic Property Levels in Runoff Containment Basins in Alabama, Louisiana, Maryland, Mississippi, and Virginia Ornamental Plant Nurseries
}

\author{
Warren E. Copes ${ }^{1}$ \\ United States Department of Agriculture, Agricultural Research Service, \\ Thad Cochran Southern Horticultural Laboratory, 810 Highway 26 West, \\ Poplarville, MS 39470
}

Haibo Zhang and Patricia A. Richardson

Hampton Roads Agricultural Research and Extension Center, Virginia Polytechnic Institute and State University, 1444 Diamond Springs Road, Virginia Beach, VA 23455

Bruk E. Belayneh

Department of Plant Science and Landscape Architecture, 2120 Plant Sciences Building, University of Maryland, College Park, MD 20742

Andrew Ristvey

Wye Research and Education Center, University of Maryland Extension, 124 Wye Narrows Drive, Queenstown, MD 21658

John Lea-Cox

Department of Plant Science and Landscape Architecture, 2120 Plant Sciences Building, University of Maryland, College Park, MD 20742

\section{Chuanxue Hong}

Hampton Roads Agricultural Research and Extension Center, Virginia Polytechnic Institute and State University, 1444 Diamond Springs Road, Virginia Beach, VA 23455

Additional index words. recycling pond, nutrient analysis, nitrogen, phosphorus, potassium, calcium, magnesium, sulfur, aluminum, boron, copper, iron, manganese, zinc, electrical conductivity, sodium

\begin{abstract}
Nine runoff containment basins (RCBs), used directly or indirectly for irrigating plants in ornamental plant nurseries, and one adjacent stream were sampled for water quality between Feb. and July 2013 in Maryland (MD), Mississippi (MS), and Virginia (VA). Triplicate water samples were taken monthly. Analysis was done for 18 water quality variables including nitrate-nitrogen $\left(\mathrm{NO}_{3}{ }^{-}-\mathrm{N}\right)$ and ammonium-nitrogen $\left(\mathrm{NH}_{4}{ }^{+}-\mathrm{N}\right)$, orthophosphate-phosphorus $\left(\mathrm{PO}_{4}-\mathrm{P}\right)$ and total-phosphorus (T-P), potassium, calcium, magnesium, sulfur, aluminum, boron $(\mathrm{B})$, copper $(\mathrm{Cu})$, iron $(\mathrm{Fe})$, manganese, zinc ( $\mathrm{Zn})$, pH, total alkalinity (T-Alk), electrical conductivity (EC), and sodium. Additionally, 15 RCBs from 10 nurseries in Alabama (AL), Louisiana (LA), and MS were sampled in 2014 and 2016. Most prevalent correlations $(P=0.01)$ were between macronutrients, EC, B, Fe, and $\mathrm{Zn}$, but none were prevalent across a majority of RCBs. Water quality parameter values were mostly present at low to preferred levels in all 25 waterways. Macronutrient levels were highest for a RCB that receives fertility from fertigation derived runoff. Water $\mathrm{pH}$ ranged from acidic to alkaline $(>8)$. Results of this study show water quality in RCBs can be suitable for promoting plant health in ornamental plant nurseries, but also shows levels will vary between individual RCBs, therefore demonstrates need to verify water quality from individual water sources.
\end{abstract}

Water quality is an important issue affecting usage of irrigation water drawn from $\mathrm{RCBs}$ in ornamental plant nurseries, because poor plant quality can result from poor water quality. Water quality characteristics are described by the status of water $\mathrm{pH}$, alkalinity, nutrient content, oxygen demand, soluble and suspended sediment, and algal populations (Chen et al., 2003, 2004; Hem, 1985; Majsztrik et al., 2011; Moss et al., 2003). Levels of residual chemical biocides, such as fungicides, herbicides, insecticides, and plant growth regulators (Mangiafico et al., 2009), and the presence of plant pathogens (Loyd et al., 2014; Parke et al., 2014) can be additional considerations that impact water quality in RCBs. In the research presented, water nutrient status and related qualities are the only measurements of water quality being considered.

Water chemistry of an RCB comprises all the soluble and suspended matter delivered from irrigation and rain runoff, as well as from contact with bottom sediment and the respiratory and metabolic products of inhabiting biotic populations (Moss et al., 2003). The biotic community that would most influence nutrient cycling consists of algae, phytobacteria, and phytoplankton (Lindstrom, 2005; Moss et al., 2003). The authors surmise that the impact of larger wildlife including fish communities and transitory visitors, such as birds and mammals, would be small to absent in RCBs.

Ornamental and vegetable plant production operations may have several sources of water, such as open waterways (e.g., streams, rivers, and lakes) and subterranean water sources (e.g., aquifers and wells), that are used for irrigation. The homogeneity or heterogeneity of water quality from open waterways, including RCBs, results from the physical dynamics of the water body that influences the extent of mixing or layering of water (Chiandet and Xenopoulos, 2016; Song et al., 2013; Zhang et al., 2015a, 2015b, 2016). The consideration of withdrawing water from an RCB for plant irrigation requires knowing the range of water properties within the water body, so levels can be predictably managed to produce quality plant material for commercial sales.

Most research has focused on the macronutrients, especially nitrogen $(\mathrm{N})$ and phosphorus $(\mathrm{P})$, associated with overflow from lakes and stormwater basins (Burgin and Hamilton, 2007; Chiandet and Xenopoulos, 2016; Hem, 1985; Lea-Cox et al., 2001; Song et al., 2015). Nitrogen and phosphorus both partly exist in labile forms. $\mathrm{NO}_{3}{ }^{-}-\mathrm{N}$ readily dissolves into water from soluble and controlled-release fertilizers where it can be easily carried in irrigation runoff to RCBs in nurseries (Mangiafico et al., 2009; Wilson et al., 2010; Yeager et al., 1993). Yeager et al. (1993) found $\mathrm{NO}_{3}^{-}-\mathrm{N}$ concentrations in runoff ranged from low levels to greater than $33 \mathrm{mg} \cdot \mathrm{L}^{-1}$. Wilson et al. (2010) recorded $\mathrm{NO}_{3}{ }^{-}-\mathrm{N}$ concentrations from 0.7 to 386.4 $\mathrm{mg} \cdot \mathrm{L}^{-1}$ and discharge runoff volumes from 7523 to $47,105 \mathrm{~L} \cdot \mathrm{ha}^{-1}$. Managing this $\mathrm{N}$ release would involve regulating water volumes and delivery events and considering bioremediation.

Runoff in urban environments has been shown to contain high quantities of soilbound particulate phosphorus and dissolved organic phosphorus as phosphomonoesters (Chiandet and Xenopoulos, 2016; Song et al., 2015). Levels of $P$ in nonalgal suspended solids and phosphomonoesters decline with distance from the inlet to outlet of urban stormwater basins during nonstorm 
conditions. During nonstormwater conditions, concentrations of algal and bacteria particulate phosphorus and the dissolved organic phosphorus as phosphodiesters increased, as much as by 12 -fold, from the inlet to the outlet of stormwater basins. Chen et al. (2004) found most water quality parameters in an RCB, including $\mathrm{N}$ and $\mathrm{P}$, were within ranges favorable for plant growth, but were at levels that contributed directly to algal blooms that caused fouling of water lines and/or contributed to additional growth of some plant selections.

RCBs are relatively small bodies of water that range in size and depth of $\approx 0.8$ to 8 ha and 0.75 to $5 \mathrm{~m}$, respectively. Despite their small size, which is similar to stormwater basins, water dynamics occur in relationship to water depth and flow from the inlet to outlet path (Chiandet and Xenopoulos, 2016; Zhang et al., 2015b). A single annual thermal stratification (monomictic) period regularly occurs from about April to October in RCBs in MD and VA (Zhang et al., 2016). Stratification results in an upper vertical water layer that has a higher temperature (as much as $21.5^{\circ} \mathrm{C}$ ), higher $\mathrm{pH}$ (as much as 4.2 units), higher dissolved oxygen (DO) (as much as $13.0 \mathrm{mg} \cdot \mathrm{L}^{-1}$, within a bottom to top range of 0.03 to $15 \mathrm{mg} \cdot \mathrm{L}^{-1}$, respectively), higher oxidation-reduction potential (ORP, as much as $505.7 \mathrm{mV}$ ), and lower EC (as low as $\left.0.9 \mathrm{dS} \cdot \mathrm{m}^{-1}\right)$ than the bottom vertical water layer (McEnroe et al., 2013; Zhang et al., 2015a, 2016). Under stratification conditions, algal communities, as measured by chlorophyll a, were densest in the middle vertical layer of the RCB (Zhang et al., 2015a). Horizontal differences down the main water flow channel occur with a lower temperature (as much as $2.8^{\circ} \mathrm{C}$ ), higher $\mathrm{pH}$ (as much as 2 units), higher DO (as much as $2.8 \mathrm{mg} \cdot \mathrm{L}^{-1}$ ), and lower ORP (as much as $290 \mathrm{mV}$ ) in the

Received for publication 19 Dec. 2016. Accepted for publication 7 Feb. 2017.

This research was supported in part by the USDA National Institute of Food and Agriculture Specialty Crop Research Initiative (agreement number 2010-51181-21140); the U.S. Department of Agriculture, Agricultural Research Service, Thad Cochran Southern Horticultural Laboratory, Southern Horticultural Research Unit project number 6404-21430-001-00D; and Virginia Agricultural Experiment Station.

We thank collaborating growers for providing access to the study reservoirs and on-site assistance.

Chuanxue Hong contributed on study's conception, and manuscript reviewing and editing. Warren Copes performed data acquisition in reservoirs in Alabama, Louisiana, and Mississippi and contributed on data analysis, manuscript drafting, and revising. Haibo Zhang and Patricia A. Richardson performed data acquisition in reservoirs in Virginia and edited the manuscript. Bruk E. Belayneh and Andrew Ristvey collected data in reservoirs in Maryland and edited the manuscript. John D. Lea-Cox contributed to manuscript reviewing and editing.

${ }^{1}$ Corresponding author. E-mail: warren.copes@ars. usda.gov. middle of the RCB than at the inlet (McEnroe et al., 2013; Zhang et al., 2015b). It is evident that water quality is neither equal in all seasons nor in all parts of a RCB.

The objective of this study was a direct assessment of water quality and nutrient ranges in multiple RCBs located in multiple states, so comparisons could be made between RCBs within and between midAtlantic and Gulf Coast regions of the United States. Since limited information on water quality in RCBs exists at this time, the objective is to document water quality measurements to better understand the range of water quality conditions present in RCBs being used for irrigation, to project potential effects on plant growth and Phytophthora zoospore survival, and to direct development of future research.

\section{Materials and Methods}

Monthly sampling and processing. Samples were collected from water sources in $\mathrm{MD}, \mathrm{MS}$, and VA. The 10 water sources were labeled first by the state abbreviation, second by a sequential numbering of the nurseries sampled within a state ( 1 or 2 ), and third by sequential numbering of RCBs (1 to 3 ) connected in series by overflow culverts, as follows: MD11, MD21, MS11, VA10, VA11, VA12, VA13, VA21, VA22, and VA23. MD11 and MD21 receive irrigation runoff directly from the production area and are direct sources for irrigation water. MS11, VA11, and VA21 receive irrigation runoff directly from the production area and indirectly serve as a source for irrigation water. VA12 and VA23 are direct sources for irrigation water, and receive overflow second or third in series, respectively, from RCBs that directly receive runoff. VA13 and VA22 neither receive runoff directly nor serve as direct sources of irrigation water, but are connected to other RCBs that serve those functions. The stream (VA10) is a local natural water source that does not receive runoff from the nursery, thus used as a comparison with VA11, VA12, and VA13. Descriptions of MD and VA RCBs and stream have been previously published using the same label designation (Zhang et al., 2015a, 2015b, 2016). A description of MS11 also was previously described (Copes et al., 2016).

All nine RCBs and one stream (VA10) in $\mathrm{MD}$, MS, and VA were sampled monthly from Feb. to July in 2013; however, water samples were not collected in every month from all 10 water sources, resulting in an incomplete design. MS11 was sampled for three additional months from Aug. to Oct. in 2013. A single set of water samples were collected monthly between $11 \mathrm{AM}$ and $1 \mathrm{PM}$ at $\approx 0.3 \mathrm{~m}$ below the RCB surface. Multiple sets of water samples were obtained from five RCBs and one stream (MD11, MD21, MS11, VA12, VA13, and VA10) in either June or July in 2013 and from MS11 in September by collecting every $2 \mathrm{~h}$ from 8:00 AM to 6:00 PM. Every sampling set consisted of three 1-L subsamples taken about $1 \mathrm{~m}$ apart from each other in a triangle pattern around a Sonde buoy located about in the center of the RCB. Water samples were collected in 1-L polycarbonate bottles in VA and MD and in 1-L polypropylene (PP) bottles in MS. All water samples were placed into an ice cooler for transport to the laboratory. Samples were divided into aliquots to nearly fill 20- and $100-\mathrm{mL}$ high-density polyethylene (HDPE) bottles in MD and MS; and 45-mL PP and 100-mL HDPE bottles in VA. Water in the 20-mL HDPE and 45-mL PP bottles were acidified with 50 or $100 \mu \mathrm{L}$, respectively, of $32 \mathrm{~N}$ sulfuric acid to preserve $\mathrm{NO}_{3}{ }^{-} \mathrm{N}$ and $\mathrm{NH}_{4}{ }^{+}-\mathrm{N}$. All aliquots were stored at $-20{ }^{\circ} \mathrm{C}$ until delivery to the analytical laboratory. All collection containers were previously treated with a $1.21 \mathrm{~N}$ hydrochloric acid wash to remove contaminants adhered to surfaces. Water analysis of monthly samples consisted of the determination of $\mathrm{NO}_{3}{ }^{-}-\mathrm{N}, \mathrm{NH}_{4}{ }^{+}-\mathrm{N}$, $\mathrm{PO}_{4}-\mathrm{P}, \mathrm{T}-\mathrm{P}$, potassium $(\mathrm{K})$, calcium $(\mathrm{Ca})$, magnesium $(\mathrm{Mg})$, sulfur $(\mathrm{S})$, aluminum (Al), $\mathrm{B}, \mathrm{Cu}, \mathrm{Fe}$, manganese ( $\mathrm{Mn}), \mathrm{Zn}, \mathrm{pH}, \mathrm{T}-\mathrm{Alk}$, EC, and sodium $(\mathrm{Na})$, and were performed by the University of Delaware Soils and Plant Analysis Laboratory, Newark, DE.

Gulf coast regional assessments. Fifteen RCBs were sampled from 10 ornamental plant container production nurseries to assess water quality variation across the Gulf Coast region, including six RCBs from four nurseries in $\mathrm{AL}$; four RCBs from three nurseries in MS; and five RCBs from three nurseries in LA. One liter of water was collected from about $0.2 \mathrm{~m}$ below the surface from about $2 \mathrm{~m}$ from the shore of each RCB. Water samples were collected in 1-L PP bottles between 9:30 AM and 3:00 PM in Aug. 2014 and between $11 \mathrm{AM}$ and $1 \mathrm{PM}$ in May 2016. Water samples were stored in an ice chest with cold packs for transportation back to the laboratory and divided into aliquots in $125 \mathrm{~mL}$ (sulfuric acid preserved), $125 \mathrm{~mL}$ (nitric acid preserved), and 250- and 500-mL HDPE bottles. Samples were stored at $-20{ }^{\circ} \mathrm{C}$ in Aug. 2014 and at $4{ }^{\circ} \mathrm{C}$ in May 2016, because samples were collected, respectively, over 3 weeks in 2014 and within $7 \mathrm{~d}$ in 2016 before shipping for analysis. Water analysis of water samples consisted of $\mathrm{NO}_{3}{ }^{-}-\mathrm{N}, \mathrm{NH}_{4}{ }^{+}-\mathrm{N}$, total-nitrogen (T-N), $\mathrm{PO}_{4}-\mathrm{P}, \mathrm{T}-\mathrm{P}, \mathrm{K}, \mathrm{Fe}, \mathrm{Mn}, \mathrm{Zn}, \mathrm{pH}, \mathrm{T}-\mathrm{Alk}$, $\mathrm{EC}$, salinity, and biochemical oxygen demand performed by Brookside Laboratories, Inc., New Bremen, OH.

Data analysis. Replications consisted of monthly means calculated from all subsets from a single or multiple sampling sets collected during a single day, with five or six replications per RCB and the stream. Monthly means were compared using analysis of variance with the MIXED procedure (version 9.4; SAS Institute Inc., Cary, NC). Fixed effect was waterways (nine RCBs and one stream) and random effect was replications. Analysis was performed on logtransformed mean water quality variables plus 0.001 to reduce heterogeneous variances that generally increased with increasing means. Goodness of fit was determined based 
on the smallest Akaike's, corrected Akaike's, and Sawa Bayesian information criterion values. The null hypothesis of all treatments being equal was tested using Tukey's multiple comparison adjustment of least squares means $(P=0.05)$. The CORR procedure was used to compute Pearson correlation coefficients to measure the strength and direction of a linear relationship between all possible pairings of the 18 water quality variables by RCB. A $P=0.01$ was used to select significant correlation coefficients.

Summary statistics for water samples taken in three states within the Gulf Coast region for Aug. 2014 and May 2016 consisted of the minimum, mean, and maximum of 19 variables by state.

\section{Results}

Means of all 18 water quality variables measured in the 9 RCBs and 1 stream were mostly within or below preferred ranges (Tables 1-5). VA11 and VA12 had the highest $\mathrm{NO}_{3}{ }^{-}-\mathrm{N}$ and T-P levels (Table 1). VA11 is the only $\mathrm{RCB}$ in this study that receives runoff from plants fertigated with soluble fertilizer, and VA12 receives overflow from VA11. K levels predominately were within the preferred range, with higher values occurring in VA11 and VA12 (Table 2). Ca, $\mathrm{Mg}$, and S levels varied from within to below preferred ranges for all RCBs (Table 2). Levels for the micronutrients were at the lower part of the preferred range for all RCBs (Tables 3 and 4).

Mean water $\mathrm{pH}$ measurements from the nine RCBs and one water way varied from neutral to alkaline (Table 5). Mean water $\mathrm{pH}$ measurements fell within the preferred $\mathrm{pH}$ range of 5.2 to $6.8 \mathrm{pH}$ units for VA10 and VA11; was higher than preferred but below an upper acceptable level of $8.0 \mathrm{pH}$ units for MD21, VA12, VA13, VA21, and VA23; and were above $8.0 \mathrm{pH}$ units for MD11 and MS11 (Table 5). Variability in $\mathrm{pH}$ range tended to be smallest, or more consistent, for the RCBs with the lowest and highest mean $\mathrm{pH}$ values, and largest for all other RCBs as represented by standard errors (Table 5).

The T-Alk means mostly were very low to low values within the preferred range ( 0 to $140 \mathrm{mg} \mathrm{CaCO}_{3} / \mathrm{L}$ ), whereas MD11 and MD21 had moderate T-Alk means (Table 5). All EC means fell within the preferred range ( 0 to $0.3 \mathrm{mmhos} \cdot \mathrm{cm}^{-1}$ ), except for water samples from VA11 that had slightly higher EC values (Table 5). Na levels mostly were in the lower part of the preferred range ( 0 to $30 \mathrm{mg} \mathrm{Na} / \mathrm{L}$ ) (Table 5), except for water samples taken from VA22 and VA23 that were at the upper part or slightly above the range.

Mean comparisons of water quality variables are most relevant between RCBs in VA that are connected because water overflows from one to the other in series. VA11 had the highest value for all macronutrients (Tables 1 and 2) and for EC (Table 5), and the highest to next highest value for micronutrients (Tables 3 and 4). Although values for VA12 were numerically lower than VA11 for all water quality variables, means were not statistically different except for $\mathrm{Cu}, \mathrm{Mn}$, and $\mathrm{Zn}$. However, levels of $\mathrm{NO}_{3}{ }^{-} \mathrm{N}, \mathrm{NH}_{4}{ }^{-} \mathrm{N}$, $\mathrm{PO}_{4}-\mathrm{P}, \mathrm{T}-\mathrm{P}, \mathrm{K}, \mathrm{Mg}, \mathrm{B}, \mathrm{Mn}, \mathrm{Zn}$, and $\mathrm{EC}$ did statistically decrease from VA12 to VA13 (Tables 1-5). In contrast, T-Alk levels increased from VA12 to VA13. Differences did not occur in $\mathrm{Ca}, \mathrm{S}, \mathrm{Al}, \mathrm{Fe}$, and $\mathrm{EC}$ levels between each of the three RCBs. The same trend was not reflected in VA21 to VA23, where water quality variable levels were low to within the preferable range in VA21. Few differences in water variable levels were measured between RCBs VA21, VA22, and VA23 (Tables 1-5).

Multiple water qualities were correlated and correlations existed between at least a few water quality variables in every waterway (Table 7). However, $75 \%$ of the 80 correlations occurred only in four of the 10 RCBs [MD21 (14), VA11 (11), VA12 (25), and VA23 (10)]. The correlations occurred in a few groupings between $\mathrm{N}, \mathrm{P}$, and $\mathrm{K}$; between EC and macronutrients; and between $\mathrm{P}, \mathrm{K}$, and micronutrients.

From the 15 RCBs sampled in the Gulf Coast region, across southern AL, southern MS, and southeastern LA, water quality variable levels mostly were low to in the preferred range (Table 6). One to two values of $\mathrm{PO}_{4}-\mathrm{P}$ and T-P were slightly above the preferred level in 2014 and 2016, and one value of $\mathrm{K}$ in 2014. The same two nurseries had the highest $\mathrm{PO}_{4}-\mathrm{P}$, T-P, and $\mathrm{K}$ values in both years (data not shown). Acidic to alkaline $\mathrm{pH}$ levels were recorded across the Gulf Coast region. T-Alk levels were very low to low in all RCBs. Salinity measurements, a slightly different test than for $\mathrm{Na}$, were either very low $\left(0.1 \mathrm{mg} \cdot \mathrm{L}^{-1}\right)$ or low $\left(100 \mathrm{mg} \cdot \mathrm{L}^{-1}\right)$ in all RCBs.

\section{Discussion}

Water quality assessments. The means of all 18 water quality variables measured in the nine RCBs and one stream were within or below water quality ranges given in a University of Arkansas extension bulletin (Robbins, 2010). The guidelines given by Robbins (2010) stated for irrigating greenhouse and nursery crops were very similar to ranges stated by several water testing laboratories (not shown). The upper ranges of a few of the water quality variables did extend above the preferred level and would be considered high, but only marginally posed potential risk. Water quality variables from the nine RCBs and one stream were similar to those found in stormwater basins, but generally lower than those reported in a composite summary of several large natural rivers, which included the MS and Amazon rivers, although this later comparison is not directly applicable to RCBs (Chiandet and Xenopoulos, 2016; Hem, 1985). Without the availability of more detailed reference sources, the conclusion at this stage is water quality in the nine RCBs

Table 1. Mean levels of $\mathrm{N}$ and $\mathrm{P}$ forms [nitrate-nitrogen $\left(\mathrm{NO}_{3}{ }^{-} \mathrm{N}\right)$, ammonium-nitrogen $\left(\mathrm{NH}_{4}{ }^{+}-\mathrm{N}\right)$, orthophosphate-phosphorus $\left(\mathrm{PO} 4^{-} \mathrm{P}\right)$, and total phosphorus (T-P)] obtained from water samples collected $1 \mathrm{~d}$ monthly from $0.3-\mathrm{m}$ depth in the approximate center of nine runoff containment basins (RCBs) and one stream (VA10).

\begin{tabular}{|c|c|c|c|c|c|c|c|c|c|}
\hline \multirow[b]{2}{*}{ Waterway ${ }^{z}$} & \multirow[b]{2}{*}{$\mathrm{n}$} & \multicolumn{2}{|c|}{$\mathrm{NH}_{4}^{+}-\mathrm{N}\left(\mathrm{mg} \cdot \mathrm{L}^{-1}\right)$} & \multicolumn{2}{|c|}{$\mathrm{NO}_{3}{ }^{-}-\mathrm{N}\left(\mathrm{mg} \cdot \mathrm{L}^{-1}\right)$} & \multicolumn{2}{|c|}{$\mathrm{PO}_{4}-\mathrm{P}\left(\mathrm{mg} \cdot \mathrm{L}^{-1}\right)$} & \multicolumn{2}{|c|}{$\mathrm{T}-\mathrm{P}\left(\mathrm{mg} \cdot \mathrm{L}^{-1}\right)$} \\
\hline & & Mean $^{y}$ & SE & Mean & SE & Mean & SE & Mean & SE \\
\hline MD11 & 6 & $0.10 \mathrm{a}$ & 0.06 & $0.06 \mathrm{a}$ & 0.02 & $0.06 \mathrm{abc}$ & 0.02 & $0.11 \mathrm{ab}$ & 0.05 \\
\hline MD21 & 5 & $0.13 \mathrm{a}$ & 0.10 & $0.83 \mathrm{c}$ & 0.20 & $0.64 \mathrm{~d}$ & 0.11 & $0.48 \mathrm{c}$ & 0.11 \\
\hline MS11 & 6 & $0.11 \mathrm{a}$ & 0.03 & $0.42 \mathrm{~b}$ & 0.22 & $0.18 \mathrm{c}$ & 0.03 & $0.19 \mathrm{ab}$ & 0.02 \\
\hline VA10 & 6 & $0.07 \mathrm{a}$ & 0.00 & $7.54 \mathrm{~d}$ & 0.32 & $0.01 \mathrm{a}$ & 0.00 & $0.03 \mathrm{a}$ & 0.01 \\
\hline VA11 & 5 & $3.73 \mathrm{~b}$ & 1.50 & $13.88 \mathrm{~d}$ & 4.71 & $2.17 \mathrm{e}$ & 0.64 & $2.29 \mathrm{~d}$ & 0.73 \\
\hline VA12 & 6 & $2.22 \mathrm{~b}$ & 1.17 & $7.31 \mathrm{~d}$ & 3.00 & $1.60 \mathrm{e}$ & 0.44 & $1.62 \mathrm{~d}$ & 0.51 \\
\hline VA13 & 5 & $0.04 \mathrm{a}$ & 0.01 & $0.43 \mathrm{ab}$ & 0.17 & $0.06 \mathrm{ab}$ & 0.02 & $0.11 \mathrm{ab}$ & 0.06 \\
\hline VA21 & 5 & $0.14 \mathrm{a}$ & 0.06 & $0.16 \mathrm{ab}$ & 0.08 & $0.02 \mathrm{ab}$ & 0.01 & $0.09 \mathrm{ab}$ & 0.02 \\
\hline VA22 & 5 & $0.16 \mathrm{a}$ & 0.08 & $0.29 \mathrm{ab}$ & 0.10 & $0.02 \mathrm{ab}$ & 0.01 & $0.06 \mathrm{ab}$ & 0.01 \\
\hline VA23 & 5 & $0.22 \mathrm{a}$ & 0.06 & $0.21 \mathrm{ab}$ & 0.08 & $0.02 \mathrm{ab}$ & 0.00 & $0.06 \mathrm{a}$ & 0.02 \\
\hline \multirow{2}{*}{\multicolumn{2}{|c|}{ Preferred range ${ }^{x}$}} & \multicolumn{2}{|c|}{$P<0.0001$} & \multicolumn{2}{|c|}{$P<0.0001$} & \multicolumn{2}{|c|}{$P<0.0001$} & \multicolumn{2}{|c|}{$P<0.0001$} \\
\hline & & \multicolumn{2}{|c|}{ NL } & \multicolumn{2}{|c|}{$0-10$} & \multicolumn{2}{|c|}{$\mathrm{NL}$} & \multicolumn{2}{|c|}{$0-1$} \\
\hline
\end{tabular}

${ }^{\mathrm{z}}$ The 10 water sources were labeled first by the state abbreviation [Maryland (MD), Mississippi (MS), and Virginia (VA)], second by a sequential numbering of the nurseries sampled within a state ( 1 or 2 ), and third by sequential numbering of RCBs ( 1 to 3 ) connected in series by overflow culverts at a single nursery.

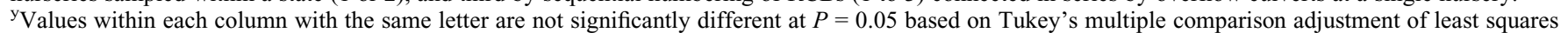

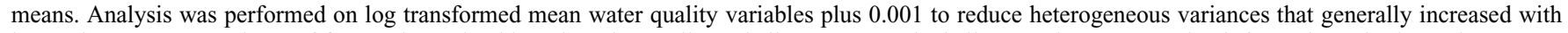
increasing means. Goodness of fit was determined based on the smallest Akaike's, corrected Akaike's, and Sawa Bayesian information criterion values.

${ }^{\mathrm{x}}$ Taken from extension bulletin (Robbins, 2010); ammonium-nitrogen and orthophosphate were not listed (NL). 
Table 2. Mean levels of some macronutrients [potassium $(\mathrm{K})$, calcium $(\mathrm{Ca})$, magnesium $(\mathrm{Mg})$, and sulfur $(\mathrm{S})$ ] obtained from water samples collected $1 \mathrm{~d}$ monthly from $0.3-\mathrm{m}$ depth in the approximate center of nine runoff containment basins (RCBs) and one stream (VA10).

\begin{tabular}{|c|c|c|c|c|c|c|c|c|c|}
\hline \multirow[b]{2}{*}{ Waterway ${ }^{z}$} & \multirow[b]{2}{*}{$\mathrm{n}$} & \multicolumn{2}{|c|}{$\mathrm{K}\left(\mathrm{mg} \cdot \mathrm{L}^{-1}\right)$} & \multicolumn{2}{|c|}{$\mathrm{Ca}\left(\mathrm{mg} \cdot \mathrm{L}^{-1}\right)$} & \multicolumn{2}{|c|}{$\mathrm{Mg}\left(\mathrm{mg} \cdot \mathrm{L}^{-1}\right)$} & \multicolumn{2}{|c|}{$\mathrm{S}\left(\mathrm{mg} \cdot \mathrm{L}^{-1}\right)$} \\
\hline & & Mean $^{y}$ & $\mathrm{SE}$ & Mean & $\mathrm{SE}$ & Mean & $\mathrm{SE}$ & Mean & $\mathrm{SE}$ \\
\hline MD21 & 5 & $8.25 \mathrm{~b}$ & 2.15 & $21.03 \mathrm{c}$ & 2.36 & $3.16 \mathrm{~b}$ & 0.53 & $9.27 \mathrm{~b}$ & 1.99 \\
\hline MS11 & 6 & $5.60 \mathrm{~b}$ & 0.22 & $15.40 \mathrm{c}$ & 0.52 & $3.60 \mathrm{~b}$ & 0.26 & $7.24 \mathrm{~b}$ & 0.68 \\
\hline VA11 & 5 & $17.59 \mathrm{c}$ & 4.72 & $16.86 \mathrm{c}$ & 2.96 & $14.11 \mathrm{~d}$ & 2.39 & $18.64 \mathrm{c}$ & 2.95 \\
\hline VA12 & 6 & $11.57 \mathrm{c}$ & 3.32 & $11.83 \mathrm{bc}$ & 2.24 & $8.18 \mathrm{~cd}$ & 1.70 & $9.60 \mathrm{bc}$ & 1.75 \\
\hline VA13 & 5 & $5.59 \mathrm{~b}$ & 0.44 & $14.47 \mathrm{bc}$ & 0.78 & $5.76 \mathrm{c}$ & 0.46 & $10.96 \mathrm{bc}$ & 0.91 \\
\hline \multirow[t]{2}{*}{ VA23 } & 5 & $2.03 \mathrm{a}$ & 0.11 & $4.70 \mathrm{a}$ & 0.49 & $1.37 \mathrm{a}$ & 0.07 & $2.46 \mathrm{a}$ & 0.28 \\
\hline & & \multicolumn{2}{|c|}{$P<0.0001$} & \multicolumn{2}{|c|}{$P<0.0001$} & \multicolumn{2}{|c|}{$P<0.0001$} & \multicolumn{2}{|c|}{$P<0.0001$} \\
\hline \multicolumn{2}{|c|}{ Preferred range ${ }^{x}$} & \multicolumn{2}{|c|}{$1-10$} & \multicolumn{2}{|c|}{$40-100$} & \multicolumn{2}{|c|}{$5-25$} & \multicolumn{2}{|c|}{$25-200$} \\
\hline
\end{tabular}

${ }^{\mathrm{z}}$ The 10 water sources were labeled first by the state abbreviation [Maryland (MD), Mississippi (MS), and Virginia (VA)], second by a sequential numbering of the nurseries sampled within a state (1 or 2), and third by sequential numbering of RCBs ( 1 to 3 ) connected in series by overflow culverts at a single nursery.

${ }^{\mathrm{y}}$ Values within each column with the same letter are not significantly different at $P=0.05$ based on Tukey's multiple comparison adjustment of least squares means. Analysis was performed on log transformed mean water quality variables plus 0.001 to reduce heterogeneous variances that generally increased with increasing means. Goodness of fit was determined based on the smallest Akaike's, corrected Akaike's, and Sawa Bayesian information criterion values.

${ }^{\mathrm{x}}$ Taken from extension bulletin (Robbins, 2010).

Table 3. Mean levels of some micronutrients [aluminum (Al), boron (B), and cooper (Cu)] obtained from water samples collected $1 \mathrm{~d}$ monthly from 0.3 -m depth in the approximate center of nine runoff containment basins (RCBs) and one stream (VA10).

\begin{tabular}{|c|c|c|c|c|c|c|c|}
\hline \multirow[b]{2}{*}{ Waterway $^{z}$} & \multirow[b]{2}{*}{$\mathrm{n}$} & \multicolumn{2}{|c|}{$\mathrm{Al}\left(\mathrm{mg} \cdot \mathrm{L}^{-1}\right)$} & \multicolumn{2}{|c|}{$\mathrm{B}\left(\mathrm{mg} \cdot \mathrm{L}^{-1}\right)$} & \multicolumn{2}{|c|}{$\mathrm{Cu}\left(\mathrm{mg} \cdot \mathrm{L}^{-1}\right)$} \\
\hline & & $\operatorname{Mean}^{y}$ & SE & Mean & SE & Mean & SE \\
\hline MD21 & 5 & $0.108 \mathrm{~cd}$ & 0.026 & $0.0296 \mathrm{~b}$ & 0.0064 & $0.0089 \mathrm{~b}$ & 0.0026 \\
\hline VA10 & 6 & $0.024 \mathrm{~b}$ & 0.004 & $0.0179 \mathrm{~b}$ & 0.0011 & $0.0007 \mathrm{a}$ & 0.0002 \\
\hline VA11 & 5 & $0.092 \mathrm{bcd}$ & 0.010 & $0.0256 \mathrm{~b}$ & 0.0042 & $0.0083 \mathrm{~b}$ & 0.0010 \\
\hline VA12 & 6 & $0.045 \mathrm{bc}$ & 0.007 & $0.0173 \mathrm{~b}$ & 0.0027 & $0.0031 \mathrm{a}$ & 0.0009 \\
\hline VA13 & 5 & $0.046 \mathrm{~b}$ & 0.009 & $0.0119 \mathrm{a}$ & 0.0011 & $0.0018 \mathrm{a}$ & 0.0007 \\
\hline \multirow[t]{2}{*}{ VA23 } & 5 & $0.077 \mathrm{bcd}$ & 0.033 & $0.0125 \mathrm{~b}$ & 0.0012 & $0.0005 \mathrm{a}$ & 0.0002 \\
\hline & & \multicolumn{2}{|c|}{$P<0.0001$} & \multicolumn{2}{|c|}{$P=0.0003$} & \multicolumn{2}{|c|}{$P<0.0001$} \\
\hline \multicolumn{2}{|c|}{ Preferred range ${ }^{\mathrm{x}}$} & \multicolumn{2}{|c|}{$0-5$} & \multicolumn{2}{|c|}{$0.2-0.5$} & \multicolumn{2}{|c|}{$0.05-0.15$} \\
\hline
\end{tabular}

${ }^{\mathrm{z}}$ The 10 water sources were labeled first by the state abbreviation [Maryland (MD), Mississippi (MS), and Virginia (VA)], second by a sequential numbering of the nurseries sampled within a state ( 1 or 2), and third by sequential numbering of RCBs ( 1 to 3 ) connected in series by overflow culverts at a single nursery.

${ }^{\mathrm{y}}$ Values within each column with the same letter are not significantly different at $P=0.05$ based on Tukey's multiple comparison adjustment of least squares means. Analysis was performed on $\log$ transformed mean water quality variables plus 0.001 to reduce heterogeneous variances that generally increased with increasing means. Goodness of fit was determined based on the smallest Akaike's, corrected Akaike's, and Sawa Bayesian information criterion values.

${ }^{\mathrm{x}}$ Taken from extension bulletin (Robbins, 2010).

Table 4. Mean levels of some micronutrients [iron ( $\mathrm{Fe})$, manganese $(\mathrm{Mn})$, and zinc $(\mathrm{Zn})$ ] obtained from water samples collected $1 \mathrm{~d}$ monthly from $0.3-\mathrm{m}$ depth in the approximate center of nine runoff containment basins (RCBs) and one stream (VA10).

\begin{tabular}{|c|c|c|c|c|c|c|c|}
\hline \multirow[b]{2}{*}{ Waterway ${ }^{z}$} & \multirow[b]{2}{*}{$\mathrm{n}$} & \multicolumn{2}{|c|}{$\mathrm{Fe}\left(\mathrm{mg} \cdot \mathrm{L}^{-1}\right)$} & \multicolumn{2}{|c|}{$\mathrm{Mn}\left(\mathrm{mg} \cdot \mathrm{L}^{-1}\right)$} & \multicolumn{2}{|c|}{$\mathrm{Zn}\left(\mathrm{mg} \cdot \mathrm{L}^{-1}\right)$} \\
\hline & & Mean $^{y}$ & $\mathrm{SE}$ & Mean & $\mathrm{SE}$ & Mean & $\mathrm{SE}$ \\
\hline MD21 & 5 & $0.062 \mathrm{a}$ & 0.004 & $0.0047 \mathrm{a}$ & 0.0033 & $0.0329 \mathrm{~d}$ & 0.0065 \\
\hline VA10 & 6 & $0.063 \mathrm{a}$ & 0.001 & $0.0628 \mathrm{c}$ & 0.0043 & $0.0078 \mathrm{bc}$ & 0.0016 \\
\hline VA11 & 5 & $0.087 \mathrm{a}$ & 0.004 & $0.3461 \mathrm{e}$ & 0.0496 & $0.0649 \mathrm{e}$ & 0.0119 \\
\hline VA12 & 6 & $0.073 \mathrm{a}$ & 0.004 & $0.0637 \mathrm{c}$ & 0.0144 & $0.0084 \mathrm{c}$ & 0.0014 \\
\hline VA13 & 5 & $0.071 \mathrm{a}$ & 0.003 & $0.0302 \mathrm{~b}$ & 0.0127 & $0.0011 \mathrm{ab}$ & 0.0004 \\
\hline \multirow{3}{*}{$\begin{array}{l}\text { VA23 } \\
\text { Preferred range }{ }^{\mathrm{x}}\end{array}$} & 5 & $0.323 \mathrm{~b}$ & 0.138 & $0.0452 \mathrm{c}$ & 0.0216 & $0.0057 \mathrm{bc}$ & 0.0028 \\
\hline & & \multicolumn{2}{|c|}{$P<0.0001$} & \multicolumn{2}{|c|}{$P<0.0001$} & \multicolumn{2}{|c|}{$P<0.0001$} \\
\hline & Preferred range $^{\mathrm{x}}$ & \multicolumn{2}{|c|}{$1-3$} & \multicolumn{2}{|c|}{$0.2-1.0$} & \multicolumn{2}{|c|}{$0.0-0.2$} \\
\hline
\end{tabular}

${ }^{\mathrm{z}}$ The 10 water sources were labeled first by the state abbreviation [Maryland (MD), Mississippi (MS), and Virginia (VA)], second by a sequential numbering of the nurseries sampled within a state (1 or 2), and third by sequential numbering of RCBs ( 1 to 3 ) connected in series by overflow culverts at a single nursery.

${ }^{y}$ Values within each column with the same letter are not significantly different at $P=0.05$ based on Tukey's multiple comparison adjustment of least squares means. Analysis was performed on log transformed mean water quality variables plus 0.001 to reduce heterogeneous variances that generally increased with increasing means. Goodness of fit was determined based on the smallest Akaike's, corrected Akaike's, and Sawa Bayesian information criterion values.

${ }^{\mathrm{x}}$ Taken from extension bulletin (Robbins, 2010).

and one stream, based on the 18 water quality variables measured, should be suitable for crop production without detrimental impact.
Macronutrients comprise the highest percent of ingredients in fertilizers. These nutrients also tend to be the most labile. Based on the classification by Robbins (2010), $\mathrm{NO}_{3}{ }^{-} \mathrm{N}$ and T-P levels were low to moderate in all $\mathrm{RCBs}$ except for VA11 and VA12 where 
Table 5. Mean levels of some electrolytic water quality variables [pH, total alkalinity (T-Alk), electrical conductivity (EC), and sodium (Na)] obtained from water samples collected $1 \mathrm{~d}$ monthly from $0.3-\mathrm{m}$ depth in the approximate center of nine runoff containment basins (RCBs) and one stream (VA10).

\begin{tabular}{|c|c|c|c|c|c|c|c|c|c|}
\hline \multirow[b]{2}{*}{ Waterway ${ }^{z}$} & \multirow[b]{2}{*}{$\mathrm{n}$} & \multicolumn{2}{|c|}{$\mathrm{pH}$ (unit) } & \multicolumn{2}{|c|}{ T-Alk $\left(\mathrm{mg} \cdot \mathrm{L}^{-1}\right)$} & \multicolumn{2}{|c|}{$\mathrm{EC}\left(\mathrm{mmhos} \cdot \mathrm{cm}^{-1}\right)$} & \multicolumn{2}{|c|}{$\mathrm{Na}\left(\mathrm{mg} \cdot \mathrm{L}^{-1}\right)$} \\
\hline & & Mean $^{y}$ & $\mathrm{SE}$ & Mean & $\mathrm{SE}$ & Mean & $\mathrm{SE}$ & Mean & $\mathrm{SE}$ \\
\hline MD21 & 5 & $7.84 \mathrm{c}$ & 0.39 & $48.81 \mathrm{e}$ & 2.06 & $0.19 \mathrm{~b}$ & 0.03 & $7.59 \mathrm{bc}$ & 1.44 \\
\hline VA11 & 5 & $6.35 \mathrm{a}$ & 0.17 & $11.05 \mathrm{ab}$ & 1.08 & $0.36 \mathrm{c}$ & 0.07 & $2.04 \mathrm{a}$ & 0.42 \\
\hline VA12 & 6 & $6.86 \mathrm{abc}$ & 0.08 & $12.53 \mathrm{~b}$ & 1.01 & $0.23 \mathrm{c}$ & 0.05 & $1.50 \mathrm{a}$ & 0.27 \\
\hline VA13 & 5 & $7.63 \mathrm{c}$ & 0.34 & $22.87 \mathrm{~d}$ & 3.25 & $0.18 \mathrm{bc}$ & 0.01 & $2.80 \mathrm{~b}$ & 0.14 \\
\hline \multirow[t]{2}{*}{ VA23 } & 5 & $7.23 \mathrm{abc}$ & 0.30 & $15.84 \mathrm{bc}$ & 2.62 & $0.19 \mathrm{bc}$ & 0.02 & $24.76 \mathrm{~d}$ & 2.76 \\
\hline & & \multicolumn{2}{|c|}{$P<0.0001$} & \multicolumn{2}{|c|}{$P<0.0001$} & \multicolumn{2}{|c|}{$P<0.0001$} & \multicolumn{2}{|c|}{$P<0.0001$} \\
\hline \multicolumn{2}{|c|}{ Preferred range $^{x}$} & \multicolumn{2}{|c|}{$5.2-6.8$} & \multicolumn{2}{|c|}{$0-140$} & \multicolumn{2}{|c|}{$0-0.30$} & \multicolumn{2}{|c|}{$0-30$} \\
\hline
\end{tabular}

${ }^{\mathrm{z}}$ The 10 water sources were labeled first by the state abbreviation [Maryland (MD), Mississippi (MS), and Virginia (VA)], second by a sequential numbering of the nurseries sampled within a state (1 or 2), and third by sequential numbering of RCBs (1 to 3 ) connected in series by overflow culverts at a single nursery.

${ }^{\mathrm{y}}$ Values within each column with the same letter are not significantly different at $P=0.05$ based on Tukey's multiple comparison adjustment of least squares means. Analysis was performed on log transformed mean water quality variables plus 0.001 to reduce heterogeneous variances that generally increased with increasing means. Goodness of fit was determined based on the smallest Akaike's, corrected Akaike's, and Sawa Bayesian information criterion values.

${ }^{\mathrm{x}}$ Taken from extension bulletin (Robbins, 2010).

Table 6. Summary statistics of water quality measurements from six runoff containment basins (RCB) in southern Alabama, five RCBs in eastern Louisiana, and four RCBs in southern Mississippi.

\begin{tabular}{|c|c|c|c|c|c|c|c|}
\hline \multirow[b]{2}{*}{ Water quality variables } & \multirow[b]{2}{*}{ Units } & \multicolumn{3}{|c|}{ May 2016} & \multicolumn{3}{|c|}{ Aug. 2014} \\
\hline & & Mean & Minimum & Maximum & Mean & Minimum & Maximum \\
\hline $\mathrm{NO}_{3}^{-}-\mathrm{N}$ & $\mathrm{mg} \cdot \mathrm{L}^{-1}$ & 1.34 & 0.05 & 7.15 & 0.80 & 0.05 & 2.92 \\
\hline T-P & $\mathrm{mg} \cdot \mathrm{L}^{-1}$ & 0.88 & 0.27 & 1.95 & 0.32 & 0.10 & 1.63 \\
\hline K & $\mathrm{mg} \cdot \mathrm{L}^{-1}$ & 4.27 & 0.62 & 12.47 & 3.86 & 0.33 & 10.06 \\
\hline $\mathrm{Fe}$ & $\mathrm{mg} \cdot \mathrm{L}^{-1}$ & 0.402 & 0.061 & 1.362 & 0.567 & 0.035 & 1.539 \\
\hline pH & SU & 7.84 & 6.18 & 9.86 & 7.29 & 5.71 & 9.76 \\
\hline T-Alk & $\mathrm{mg} \cdot \mathrm{L}^{-1}$ & 22.67 & 4.00 & 48.00 & 19.87 & 8.00 & 44.00 \\
\hline $\mathrm{EC}$ & umhos $\mathrm{cm}^{-1}$ & 99.69 & 23.80 & 224.00 & 87.47 & 24.63 & 141.10 \\
\hline Salinity & $\mathrm{mg} \cdot \mathrm{L}^{-1}$ & 53.93 & 0.05 & 109.00 & 53.36 & 0.05 & 100.00 \\
\hline BOD & $\mathrm{mg} \cdot \mathrm{L}^{-1}$ & 3.01 & 0.50 & 5.91 & 4.66 & 0.50 & 9.27 \\
\hline
\end{tabular}

$\mathrm{NH}_{4}{ }^{+}-\mathrm{N}=$ ammonium-nitrogen; $\mathrm{NO}_{3}{ }^{-}-\mathrm{N}=$ nitrate-nitrogen; $\mathrm{T}-\mathrm{N}=$ total-nitrogen; $\mathrm{PO}_{4}-\mathrm{P}=$ orthophosphate-phosphorus; $\mathrm{T}-\mathrm{P}=$ total phosphorus; $\mathrm{K}=$ potassium; $\mathrm{Fe}=$ iron; $\mathrm{Mn}=$ manganese; $\mathrm{Zn}=$ zinc; $\mathrm{T}-\mathrm{Alk}=$ total alkalinity; $\mathrm{EC}=$ electrical conductivity; $\mathrm{BOD}=$ biochemical oxygen demand.

Table 7. The number of waterways out of a total of 10 (nine runoff containment basins and one stream) that had a positive correlation (upper right diagonal half) and/or a negative correlation (lower left diagonal half) between two variables with $P=0.01$.

\begin{tabular}{|c|c|c|c|c|c|c|c|c|c|c|c|c|c|c|c|c|c|c|}
\hline & $\mathrm{NH}_{4}{ }^{\mathrm{z}}$ & $\mathrm{NO}_{3}$ & $\mathrm{PO}_{4}$ & T-P & $\mathrm{K}$ & $\mathrm{Ca}$ & $\mathrm{Mg}$ & $\mathrm{S}$ & $\mathrm{pH}$ & Alk & EC & $\mathrm{Na}$ & $\mathrm{Al}$ & B & $\mathrm{Cu}$ & $\mathrm{Fe}$ & $\mathrm{Mn}$ & $\mathrm{Zn}$ \\
\hline $\mathrm{NH}_{4}$ & $\mathrm{NH}_{4}$ & 2 & 1 & 1 & 1 & 0 & 0 & 0 & 0 & 1 & 0 & 0 & 0 & 0 & 0 & 0 & 1 & $\overline{0}$ \\
\hline $\mathrm{PO}_{4}$ & 0 & 0 & $\mathrm{PO}_{4}$ & 2 & 2 & 1 & 0 & 0 & 0 & 0 & 1 & 0 & 0 & 1 & 0 & 1 & 0 & 1 \\
\hline T-P & 0 & 0 & 0 & T-P & 3 & 0 & 0 & 0 & 0 & 1 & 1 & 0 & 0 & 1 & 0 & 2 & 0 & 1 \\
\hline $\mathrm{Ca}$ & 0 & 0 & 0 & 0 & 0 & $\mathrm{Ca}$ & 2 & 2 & 0 & 0 & 1 & 2 & 0 & 0 & 0 & 0 & 0 & 2 \\
\hline $\mathrm{Mg}$ & 0 & 0 & 0 & 0 & 0 & 0 & $\mathrm{Mg}$ & 1 & 0 & 0 & 3 & 1 & 0 & 0 & 0 & 0 & 0 & 0 \\
\hline S & 0 & 0 & 0 & 0 & 0 & 0 & 0 & $\mathrm{~S}$ & 0 & 0 & 1 & 1 & 0 & 0 & 0 & 0 & 0 & 0 \\
\hline $\mathrm{EC}$ & 0 & 0 & 0 & 0 & 0 & 0 & 0 & 0 & 0 & 0 & EC & 2 & 0 & 1 & 0 & 0 & 0 & 1 \\
\hline $\mathrm{Na}$ & 0 & 0 & 0 & 0 & 0 & 0 & 0 & 0 & 1 & 0 & 0 & $\mathrm{Na}$ & 0 & 1 & 0 & 0 & 0 & 0 \\
\hline $\mathrm{Al}$ & 0 & 0 & 0 & 0 & 0 & 0 & 0 & 0 & 0 & 0 & 0 & 0 & $\mathrm{Al}$ & 0 & 0 & 0 & 0 & 0 \\
\hline B & 0 & 0 & 0 & 0 & 0 & 0 & 0 & 0 & 0 & 0 & 0 & 0 & 0 & B & 1 & 0 & 0 & 1 \\
\hline $\mathrm{Cu}$ & 0 & 0 & 0 & 0 & 0 & 0 & 0 & 0 & 0 & 0 & 0 & 0 & 0 & 0 & $\mathrm{Cu}$ & 0 & 0 & 1 \\
\hline $\mathrm{Fe}$ & 0 & 0 & 0 & 0 & 0 & 1 & 1 & 0 & 0 & 0 & 0 & 0 & 1 & 0 & 0 & $\mathrm{Fe}$ & 0 & 0 \\
\hline $\mathrm{Mn}$ & 0 & 0 & 0 & 0 & 0 & 0 & 0 & 0 & 0 & 0 & 0 & 0 & 0 & 0 & 0 & 0 & $\mathrm{Mn}$ & 1 \\
\hline
\end{tabular}

${ }^{\mathrm{z}}$ Eighteen water quality variables: nitrate-nitrogen $\left(\mathrm{NO}_{3}{ }^{-} \mathrm{-N}\right)$, ammonium-nitrogen $\left(\mathrm{NH}_{4}{ }^{+}-\mathrm{N}\right)$, orthophosphate-phosphorus $\left(\mathrm{PO}_{4}-\mathrm{P}\right)$, total phosphorus $(\mathrm{T}-\mathrm{P})$, potassium $(\mathrm{K})$, calcium $(\mathrm{Ca})$, magnesium $(\mathrm{Mg})$, sulfur $(\mathrm{S})$, aluminum $(\mathrm{Al})$, boron $(\mathrm{B})$, copper $(\mathrm{Cu})$, iron $(\mathrm{Fe})$, manganese $(\mathrm{Mn})$, zinc $(\mathrm{Zn})$, pH, total alkalinity (Alk), electrical conductivity (EC), and sodium (Na).

upper values extended above the preferred range (Table 1). Putting this in perspective, the upper levels recorded were still considerably less than rates recommended for promoting plant growth. Chen et al. (2003) also measured low levels of $\mathrm{NO}_{3}{ }^{-}-\mathrm{N}$ $\left(0.04 \mathrm{mg} \cdot \mathrm{L}^{-1}\right)$ and $\mathrm{T}-\mathrm{P}\left(0.87 \mathrm{mg} \cdot \mathrm{L}^{-1}\right)$ in an RCB. An initial conclusion is RCBs have the chemical and biological capacity to convert 
and use N, P, and other macronutrient forms (Chiandet and Xenopoulos, 2016; Song et al., 2015). However, we lack a measure of how much stormwater flows dilute and flush nutrients from each RCB (Chiandet and Xenopoulos, 2016).

Chemical and biological conversions of $\mathrm{N}$ and $\mathrm{P}$ have been characterized in other waterways than RCBs, such as in stormwater basins. $\mathrm{NO}_{3}{ }^{-} \mathrm{N}$ is the most soluble and mobile form of $\mathrm{N}$ and denitrification is the main process converting it to other $\mathrm{N}$-forms, such as nitrogen gas $\left(\mathrm{N}_{2}\right)$ that is released into the atmosphere (Burgin and Hamilton, 2007). Denitrification likely would be occurring in the anoxic zones of the RCB during summer stratification periods when fertilizer is most heavily applied. Phosphorus also undergoes multiple reactions. Song et al. (2015) measured low levels of $\mathrm{P}$ with a mean T-P of $0.056 \mathrm{mg} \cdot \mathrm{L}^{-1}$ in nine urban stormwater basins. Despite the low levels, Song et al. (2015) found P in multiple forms. The predominate form of dissolved organic $\mathrm{P}$ shifted from phosphomonoesters at the inflow to phosphodiesters at the outflow, whereas T-P was higher in the middle of the basin, which corresponds to the location of samples taken for this study. Particulate-P increased toward the outflow, likely associated with the assimilation of dissolved-P by algae and bacteria that converted it to particulate $\mathrm{P}$ forms. Phosphorus is considered a limiting nutrient for phytoplankton production in freshwater systems (Rabalais, 2001). Algae and phytoplankton communities have not been characterized in RCBs, although algal blooms are evident in many RCBs during summer months. Algae and phytoplankton colonizing soil at the bottom of RCBs (benthic) and vertical zones of the water body (sestonic) would use these nutrients. Morphometric pond variables (pond depth, length:width ratio, and area:perimeter ratio) can serve as predictors of water quality that affect $\mathrm{N}$ and T-P levels (Chiandet and Xenopoulos, 2016). Stormwater ponds with simple circular shapes and without forebays have higher levels of T-P than deeper ponds with sinuous shorelines. Most of the RCBs in ornamental plant nurseries have an intermediate irregularity to their oval shape, thus few of them have all the morphometric features deemed beneficial. Low DO levels in bottom water layers can also promote release of $\mathrm{P}$ from sediments (Chiandet and Xenopoulos, 2016). Understanding the chemical and biological cycling of where nutrients accumulate, under what conditions and in what form, along with hydrological cycling involving rain, evaporation and stormwater flow, and capacity of the system is still evolving.

Micronutrient levels followed the same trend as macronutrients of being below or at the lower part of the preferred range listed by Robbins (2010). Chen et al. (2003) also measured micronutrients in the lower preferred range. In our study, samples were only collected from the upper horizontal water strata (epilimnion) in the center of RCBs. Water quality levels in other zones of the
$\mathrm{RCB}$, such as the lower horizontal water strata (hypolimnion) were not measured. A larger national sampling of RCBs in more regions might find levels of $\mathrm{Fe}$ and $\mathrm{Mn}$ to be high enough to negatively affect water quality. Although $\mathrm{Cu}$ levels were low in the epilimnion of the RCBs sampled, $\mathrm{Cu}$ levels could differ in other zones, such as the hypolimnion. $\mathrm{Cu}$ is relatively immobile if assimilated by benthic biota and if bound to soil in RCB bottoms. Some of the di- and trivalent micronutrients, such as $\mathrm{Al}, \mathrm{Cu}, \mathrm{Mn}$, and $\mathrm{Zn}$, have potential to be toxic to $P h y$ tophthora zoospores. For example, if $\mathrm{Cu}$ levels attained the upper scale of the preferred range $(0.15 \mathrm{mg} \mathrm{Cu} / \mathrm{L})$ (Table 3$)$ zoospores of many Phytophthora sp. might be inactivated (Erwin and Ribeiro, 1996).

The nurseries in VA provided an interesting comparison due to differences in fertilizer delivery and water overflowing into successive RCBs connected in series. Fertilizer at VA1 is delivered in a soluble form as liquid fertigation on a regular schedule. Water quality variables in VA11 ranged from the upper part of the preferred range to a little above that level (Tables 1-5). A concern exists whether this can create an imbalance with applied fertilizer rates. P toxicity has been reported for some plants, such as Ilex crenata, when a higher than optimum level of $P$ resulted from a combination of fertilizer in the plant media and from irrigation water when $\mathrm{K}$ levels were low (Wright and Niemiera, 1987). However, fairly dramatic reductions in many of the water quality variables occurred from VA11 and VA12 to VA13. More of the water quality levels were within the preferred range in VA12 from which water is pumped for irrigation (Tables 1-5). In contrast, fertilizer at VA2 is delivered to plants from control-release fertilizer. Water quality variable levels in VA21 ranged from low to within the preferred range. Few differences in water quality variable levels existed between RCBs VA21, VA22, and VA23 (Tables 1-5). These limited comparisons seem to demonstrate that a single RCB has more capacity to use nutrients when they are low, but the capacity of that system may be challenged when nutrient levels are higher than the preferred range. The limited comparison is extended to show the possibility that multiple RCBs in series provide added capacity to lower nutrient levels in successive RCBs.

The fact that nutrients were low in many of the RCBs shows plant toxicity was not an issue; furthermore, some RCBs do not provide a measurable contribution to plant fertility. An issue that needs further consideration is determining whether elevated levels of nutrients that are still below fertility recommendations contribute an additive effect that could cause nutritional imbalances in plant fertility.

Mean $\mathrm{pH}$ measurements varied between $\mathrm{RCBs}$ and the range varied within RCBs (Table 5). Mean $\mathrm{pH}$ measurements were within the preferred $\mathrm{pH}$ range $(5.2$ to $6.8 \mathrm{pH}$ units) for two RCBs (VA11 and VA12); higher than preferred but below an upper acceptable level (8.0 pH units) for four RCBs (MD21, VA13, VA21, and VA23) and one stream (VA10); and above $8.0 \mathrm{pH}$ units for three RCBs (MD11, MD21, and MS11). Table 5 gives the impression that RCBs in $\mathrm{MS}$ and MD might have higher $\mathrm{pH}$ values, yet Table 6 shows a larger range of $\mathrm{pH}$ ranges occurred when a greater number of RCBs were sampled in AL, LA, and MS, similar to the range in $\mathrm{MD}, \mathrm{MS}$, and VA. Most $\mathrm{pH}$ values in this study were taken about near noon to minimize diurnal influences (Zhang et al., 2016). The diurnal fluctuation in $\mathrm{pH}$ of surface water, as well as $\mathrm{DO}$, is related to respiration and photosynthetic activities of algal and phytoplankton populations (Hong et al., 2009). Annual pH ranges would still be influenced by other seasonal and chemical aspects of individual RCBs, such as alkalinity.

$\mathrm{RCBs}$ in this study were characterized predominately by very low to low T-Alk means, low to moderate EC means, and low $\mathrm{Na}$ or salinity means (Tables 5 and 6). Alkalinity is an acid-neutralizing capacity of carbonates in water to buffer $\mathrm{pH}$ changes, whereby more rapid and wider $\mathrm{pH}$ fluctuations will occur with lower T-Alk levels. EC is the overall EC generated by all ions. The lower EC values indicate RCBs have the capacity to absorb the EC levels delivered in runoff, although as stated the influence from stormwater is unknown. Chen et al. (2003) recorded similar measurements for $\mathrm{pH}$, T-Alk, and EC in a research-constructed RCB. Na levels were not a problem in most of the RCBs. Na was at the upper part of the range for water samples collected from VA22 and VA23, thus an issue that needs monitoring.

Fifteen RCBs were sampled in southern $\mathrm{AL}$, southern MS, and southeastern LA to measure diversity of water quality across the Gulf Coast region (Table 6). Ranges for the 14 water qualities measured in AL, LA, and MS were similar to ranges from MD, MS, and VA, which provide further evidence that water quality variables measured may be acceptable as an irrigation water source from many RCBs. Yet, the spotty detection of correlations in Table 7 shows no prominent repeatable effect in RCBs and indicates a complexity to these systems might exist that makes it difficult to generalize about potential interactions.

Management considerations. In the studies being reported, levels of water quality variables ranged from low to preferable levels, thus indicating good irrigation water quality for the variables tested. Even though Robbins (2010) listed the ranges as preferred, the basis for these values have not been thoroughly researched. Chen et al. (2003) showed commercial marketable plants were produced using RCBs as a source for irrigation water. The RCBs tested in AL, LA, MD, MS, and VA in this study demonstrate that same result, as these RCBs are actively used as a source of irrigation without any noticeable reduction in plant quality. Chen et al. (2004) produced plant quality equal to or better than plants watered from a well. In 
contrast, Meador et al. (2012) identified a lower water quality from $24 \mathrm{RCBs}$ in nine states than from municipal and well water sources based on total dissolved solids (TDS). Concerns about TDS include clogging of emitters and interference with water sanitation treatments, such as ultraviolet light. These problems do exist, however, they are not derived solely from TDS levels, but also from mineral salts accretion and biofilm growth in irrigation lines.

Accumulation and movement of solutes in RCBs have not yet been incorporated as a fertility management tool. It may not always be clear whether water quality from an RCB is negatively or positively affecting crop quality. Grower concern exists whereby water from some RCBs is applied only on hardier plants. The problem is RCBs are complex dynamic systems that will require understanding interactions between water chemistry processes, sestonic and benthic biological activity, and weather influences. Because of the importance of water, the RCB capacity and water quality management need to be better understood (Wilson et al., 2010).

Several RCBs had $\mathrm{pH}$ values at 8.0 or above and could require acidification treatment before applying certain disinfestant treatments, such as chlorine gas, peroxygen compounds, and ozone. Fortunately, T-Alk levels were low enough that only low acid rates would be required in these specific cases. As an alternative approach, water could be drawn during morning hours when water is more acidic, which occurs due to a diurnal $\mathrm{pH}$ change in response to the metabolic activity of algae (Hong et al., 2009). Additional opportunity exists by drawing water from deeper depths where it is more acidic than surface water during stratification periods from April to October (Zhang et al., 2016). Zhang et al. (2016) demonstrated the occurrence of stratification in some of the same RCBs (MD11, MD21, VA11, VA12, VA13, VA21, VA22, and VA23) sampled in 2013. High $\mathrm{pH}$ levels could potentially cause an interaction with plant nutrient solubility, particularly micronutrients such as $\mathrm{Fe}$ and $\mathrm{Zn}$. However, low water alkalinity values allow for rapid $\mathrm{pH}$ change, as a result buffered organic growing media would readily compensate and shift water to the desired $\mathrm{pH}$ to allow nutrient availability and uptake by plants (Chen et al., 2004). In such cases, plants should be monitored for micronutrient deficiencies and fertilized according to extension recommendations.

Influence on plant pathogens. Dispersal of plant pathogenic Phytophthora sp. in irrigation water is well documented and a primary concern of plant industries (Ghimire et al., 2011; Loyd et al., 2014; Parke et al., 2014). Water quality has been shown to reduce survival of several plant pathogenic Phytophthora sp. to as short as $1 \mathrm{~d}$ (Kong and Hong, 2014; Kong et al., 2012a, 2012b; Kong and Lea-Cox, 2014). Information about how Phytophthora sp. survive and traverse the aquatic environment of RCBs is in its in- fancy. Of the RCBs in this study, even the higher mean EC values of 0.23 to 0.36 $\mathrm{mmho} \cdot \mathrm{cm}^{-1}\left(0.23\right.$ to $\left.0.36 \mathrm{dS} \cdot \mathrm{m}^{-1}\right)$ would be unfavorable for the long-term survival of Phytophthora alni, Phytophthora kernoviae, and Phytophthora ramorum zoospores that favored an EC $>1.89 \mathrm{dS} \cdot \mathrm{m}^{-1}$ (Kong et al., 2012a). Chen et al. (2003) also measured ECs lower than $0.6 \mathrm{mmho} \cdot \mathrm{cm}^{-1}$. These results are encouraging, yet too few Phytophthora species have been evaluated to understand the larger ecological implications of EC on zoospore longevity and how variable the response might be by Phytophthora species. The influence of $\mathrm{pH}$ on zoospore longevity varies by Phytophthora species. Of Phytophthora species that have been evaluated, preferred $\mathrm{pH}$ for zoospore longevity over $7 \mathrm{~d}$ was $\mathrm{pH} 5$ to 11 for $P$. alni and $P$. ramorum; $\mathrm{pH} 9$ for Phytophthora citricola; $\mathrm{pH} 7$ for Phytophthora citrophthora, Phytophthora insolita, Phytophthora irrigata, Phytophthora megasperma, and Phytophthora nicotianae; $\mathrm{pH} 5$ for Phytophthora tropicalis; and $\mathrm{pH} 3$ to 9 for P. kernoviae (Kong et al., 2009, 2012b). Since RCBs vary in $\mathrm{pH}$ means and standard errors (Table 5), this brings into question whether survivability of Phytophthora sp. will be more favored in some RCBs than in others. Higher preferred levels of some micronutrients (Tables 3 and 4) could further reduce the survivability of zoospores without being detrimental to plant growth. It is known that some Phytophthora species are commonly recovered in RCBs, such as Phytophthora gonapodyides, Phytophthora hydropathica, P. irrigata, and Phytophthora chlamydospora (Copes et al., 2016; Ghimire et al., 2011; Loyd et al., 2014; Parke et al., 2014), these species may be more tolerant of low ECs and a wider $\mathrm{pH}$ range than the more virulent plant pathogenic Phytophthora species reported by Kong et al. (2012a). A picture is developing that shows various water quality variables $(\mathrm{EC}, \mathrm{DO}$, and $\mathrm{pH}$ ) could affect the population of Phytophthora species in RCBs. Additional research is needed to better understand the potential of zoospore survival within the main water body and niche habitats of RCBs, to characterize the risk of pathogen spread in irrigation water and to better understand the potential for developing management techniques that limit pathogen dispersal.

\section{Conclusions}

The primary conclusion is nutrient, $\mathrm{pH}$, alkalinity, and ionic water quality of many RCBs provides water suitable for irrigating ornamental plants in commercial nursery production. Because levels of water quality variables varied among individual $\mathrm{RCBs}$, it would be judicious for producers to take at least one complete water analysis to have a minimum measure of the nature of an RCB. This information is essential for evaluating the plant health of plant selections exhibiting poor or abnormal growth, the possibility of promoting pathogen decline along the water path in RCBs, and the efficacy of irrigation water disinfectant treatments. This study also provides a framework for future studies on how individual nutrient elements in water may affect pathogen survival in RCBs. Despite RCBs being relatively small waterways, research is needed to understand horizontal and vertical water dynamics of water properties, nutrient kinetics, and biological ecology to develop practical RCB water management tools. Monitoring water quality in RCBs adds a further consideration to the existing tactics used for meeting irrigation needs that include precision irrigation delivery, irrigation durations, plant container density, monitoring leaching fractions, and precision delivery of nutrients by zones within a nursery (Itier and Brisson, 2011; Lea-Cox et al., 2001; Stirzaker, 2011; Warsaw et al., 2009).

\section{Literature Cited}

Burgin, A.J. and S.K. Hamilton. 2007. Have we overemphasized the role of denitrification in aquatic ecosystems? A review of nitrate removal pathways. Front. Ecol. Environ. 5:8996.

Chen, J.J., R.C. Beeson, and R.L. Snyder. 2004. Production of quality aroid foliage plants using captured rainwater and irrigation runoff as an irrigation source. Acta Hort. 664:139-145.

Chen, J., R.C. Beeson, T.H. Yeager, R.H. Stamps, and L.A. Felter. 2003. Evaluation of captured rainwater and irrigation runoff for greenhouse foliage and bedding plant production. HortScience 38:228-233.

Chiandet, A.S. and M. Xenopoulos. 2016. Landscape and morphometric controls on water quality in stormwater management ponds. Urban Ecosyst. 19:1645-1663.

Copes, W.E., X. Yang, and C.X. Hong. 2016 Phytophthora species recovered from irrigation reservoirs in Mississippi and Alabama nurseries and pathogenicity of three new species. Plant Dis. 99:1390-1395.

Erwin, D.C. and O.K. Ribeiro. 1996. Phytophthora diseases worldwide. APS Press, St. Paul, MN.

Ghimire, S.R., P.A. Richardson, P. Kong, J. Hu, J.D. Lea-Cox, D.S. Ross, G.W. Moorman, and C. Hong. 2011. Distribution and diversity of Phytophthora species in nursery irrigation reservoir adopting water recycling system during winter months. J. Phytopathol. 159:713-719

Hem, J.D. 1985. Study and the interpretation of chemical characteristics of natural water. U.S Geolog. Surv. Water Supply Paper 2254

Hong, C., J.D. Lea-Cox, D.S. Ross, G.W. Moorman, P A. Richardson, S.R. Ghimire, and P. Kong. 2009. Containment basin water quality fluctuation and implications for crop health management. Irr. Sci. 27:485-496.

Itier, B. and N. Brisson. 2011. Improvement of water use for agriculture at catchment level under drought conditions. Acta Hort. 889:27-40.

Kong, P. and C. Hong. 2014. Oxygen stress reduces zoospore survival of Phytophthora species in a simulated aquatic system. BMC Microbiol. 14:124

Kong, P. and J.D. Lea-Cox. 2014. Water quality dynamics and influences on pathogen mitigation in irrigation reservoirs, p. 333-346. In: C.X. Hong, G.W. Moorman, W. Wohanka, and C. Buettner (eds.). Biology, detection and management of plant pathology in irrigation water. APS Press, St. Paul, MN 
Kong, P., J.D. Lea-Cox, and C.X. Hong. 2012a. Effect of electrical conductivity on survival of Phytophthora alni, P. kernoviae and $P$. ramorum in a simulated aquatic environment. Plant Pathol. 61:1179-1186.

Kong, P., J.D. Lea-Cox, G.W. Moorman, and C.X Hong. 2012b. Survival of Phytophthora alni, Phytophthora kernoviae, and Phytophthora ramorum in a simulated aquatic environment at different levels of $\mathrm{pH}$. FEMS Microbiol. Lett. 332:54-60.

Kong, P., G.W. Moorman, J.D. Lea-Cox, D.S. Ross, P.A. Richardson, and C.X. Hong. 2009. Zoosporic tolerance to $\mathrm{pH}$ stress and its implications for Phytophthora species in aquatic ecosystems. Appl. Environ. Microbiol. 75:4307-4314.

Lea-Cox, J.D., D.S. Ross, and K.M. Teffeau. 2001. A water and nutrient management planning process for container nursery and greenhouse production systems in Maryland. J. Environ. Hort. 19:230-236.

Lindstrom, E.S. 2005. Distribution of typical freshwater bacterial groups is associated with $\mathrm{pH}$, temperature, and lake water retention time. Appl. Environ. Microbiol. 71:8201-8206.

Loyd, A.L., D.M. Benson, and K.L. Ivors. 2014. Phytophthora populations in nursery irrigation water in relationship to pathogenicity and infection frequency of Rhododendron and Pieris. Plant Dis. 98:1213-1220.

Majsztrik, J.C., A.G. Ristvey, and J.D. Lea-Cox. 2011. Water and nutrient management in the production of container-grown ornamentals. Hort. Rev. 38:253-297.

Mangiafico, S.S., J. Newman, D.J. Merhaut, J. Gan, B. Faber, and L. Wu. 2009. Nutrients and pesticides in stormwater runoff and soil water in production nurseries and citrus and avocado groves in California. HortTechnology 19:360-367.

McEnroe, N.A., J.M. Buttle, J. Marsalek, F.R. Pick, M.A. Xenopoulos, and P.C. Frost. 2013. Thermal and chemical stratification of urban ponds: Are they 'completely mixed reactors'? Urban Ecosyst. 6:327-339.
Meador, D.P., P.R. Fisher, P.F. Harmon, N.A. Peres, M. Teplitski, and C.L. Guy. 2012. Survey of physical, chemical, and microbial water quality in greenhouse and nursery irrigation water. HortTechnology 22:778-786.

Moss, B., D. Stephen, C. Alvarez, E. Becares, W. van de Bund, S.E. Collings, E. van Donk, E. de Eyto, T.O. Feldmann, C. FernándezAláez, M. Fernández-Aláez, R.J.M. Franken, F. Gracía-Criado, E.M. Gross, M. Gyllstrõm, L.A. Hansson, K. Irvine, A. Järvalt, J.P. Jensen, E. Jeppesen, T. Kairesalo, R. Kornijów, T. Krause, H.K. Uunnap, A. Laas, E. Lill, B. Lorens, H. Luup, M.R. Miracle, P. Nõges, T. Nõges, M.N. Aaneni, I. Ott, W. Peczula, E.T.H.M. Peeters, G. Phillips, S. Romo, V. Russell, J. Salujõe, M. Scheffer, K. Siewertsen, H. Smal, C. Tesch, H. Timm, L. Tuvikene, I. Tonno, T. Virro, E. Vicente, and D. Wilson. 2003. The determination of ecological status in shallow lakes: A tested system (ECOFRAME) for implementation of the European Water Framework Directive. Aquat. Conserv. Mar. Freshw. Ecosyst. 13:507-549.

Parke, J.L., B.J. Knaus, V.J. Fieland, C. Lewis, and N.J. Grüenwald. 2014. Phytophthora community structure analyses in Oregon nurseries inform systems approaches to disease management. Phytopathology 104:1052-1062.

Rabalais, N.N. 2001. Nitrogen in aquatic ecosystems. AMBIO: J. Human Environ. 31:102112.

Robbins, J. 2010. Irrigation water for greenhouses and nurseries. Univ. Arkansas Coop. Ext. Ser. Agr. Nat. Resources Bull. FSA6061-PD-5-10RV.

Song, K., M.A. Xenopoulos, J.M. Buttle, J. Marsalek, N.D. Wagner, F.R. Pick, and P.C. Frost. 2013. Thermal stratification patterns in urban RCBs and their relationships with vertical nutrient gradients. J. Environ. Mgt. 127:317-323.

Song, K., M.A. Xenopoulos, J. Marsalek, and P.C. Frost. 2015. The fingerprints of urban nutrients: Dynamics of phosphorus speciation in water flowing through developed landscapes. Biogeochemistry 125:1-10.

Stirzaker, R.J. 2011. Strategy, tactics and heuristics for managing solutes in horticultural crops. Acta Hort. 889:59-66.

Warsaw, A.L., R.T. Fernandez, B.M. Cregg, and J.A. Andresen. 2009. Water conservation, growth, and water use efficiency of containergrown woody ornamentals irrigated based on daily water use. HortScience 44:1-11.

Wilson, C., J. Albano, M. Mozdzen, and C. Riiska. 2010. Irrigation water and nitrate-nitrogen loss characterization in southern Florida nurseries: Cumulative volumes, runoff rates, nitratenitrogen concentrations and loadings, and implications for management. HortTechnology 20:325-330.

Wright, R.D. and A.X. Niemiera. 1987. Nutrition of container-grown woody nursery crops. Hort. Rev. 9:75-101.

Yeager, T., R. Wright, D. Fare, C. Gilliam, J. Johnson, T. Bilderback, and R. Zondag. 1993. Six state survey of container nursery nitrate nitrogen runoff. J. Environ. Hort. 11:206-208.

Zhang, H., P.A. Richardson, B.E. Belayneh, A. Ristvey, J. Lea-Cox, W.E. Copes, G.W. Moorman, and C. Hong. 2015a. Characterization of water quality in stratified nursery recycling irrigation reservoirs. Agr. Water Mgt. 160:76-83.

Zhang, H., P.A. Richardson, B.E. Belayneh, A. Ristvey, J. Lea-Cox, W.E. Copes, G.W. Moorman, and C. Hong. 2015b. Comparative analysis of water quality between runoff entrance and middle of recycling irrigation reservoirs. Water 7:3861-3877.

Zhang, H., P.A. Richardson, B.E. Belayneh, A. Ristvey, J. Lea-Cox, W.E. Copes, G.W. Moorman, and C. Hong. 2016. Recycling irrigation reservoir stratification and implications for crop health and production. J. Amer. Water Resources 52:620631. 